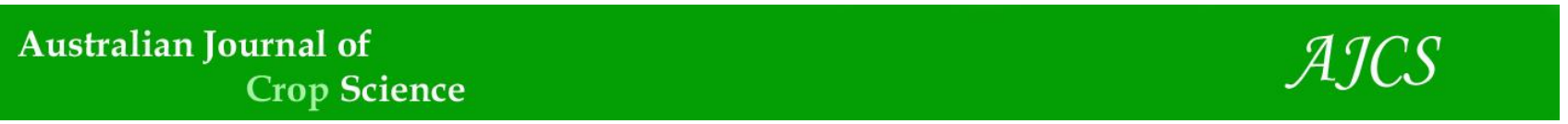

AJCS 14(07):1064-1071 (2020)

ISSN:1835-2707

doi: 10.21475/ajcs.20.14.07.p2049

\title{
Production and quality of zucchini seeds after applying sulphur as top dressing and organic compost at planting
}

\author{
Estefânia Martins Bardiviesso ${ }^{1 *}$, Natália de Brito Lima Lanna ${ }^{1}$, Ariel Santivañez Aguilar ${ }^{1}$, Sara Raissa Brito \\ Bezerra ${ }^{1}$, Raíra Andrade Pelvine ${ }^{1}$, Pâmela Gomes Nakada Freitas ${ }^{2}$, Francisca Zildélia da Silva ${ }^{1}$, Marcela \\ Sant' Anna Cordeiro da Silva ${ }^{3}$, Antonio Ismael Inácio Cardoso ${ }^{1}$
}

${ }^{1}$ School of Agriculture, São Paulo State University, Botucatu, Sao Paulo, Brazil
${ }^{2}$ School of Agriculture, São Paulo State University, Dracena, Sao Paulo, Brazil
${ }^{3}$ School of Agriculture, São Paulo State University, Piracicaba, Sao Paulo, Brazil

*Corresponding author: estefania.bardiviesso@hotmail.com

Abstract

The recommendation of fertilization for zucchini (Cucurbita pepo) cultivation is usually made with no differentiation from the other cucurbit crops. Thus, there is a need to examine the doses of fertilizers used for zucchini production, as well as the suitability for cultivars, seasons, and cultivation regions. The aim of this study was to evaluate the influence of sulfur doses at topdressing fertilization and the supply of organic compost at planting on the production and quality of zucchini seeds. A total of eight treatments were studied in a randomized block design with a factorial scheme $4 \times 2$, corresponding to four sulfur doses at topdressing $\left(0,57,114\right.$ and $173 \mathrm{~kg} \mathrm{ha}^{-1}$ of S), in the presence $\left(30 \mathrm{t} \mathrm{ha}^{-1}\right)$ and absence of organic compost at planting. The fruits were harvested $62 \mathrm{DAT}$, and after harvest, the fruits remained in rest for 15 days in order to reach the uniformity of the physiological maturity of the seeds. The production characteristics evaluated were average fresh weight, diameter, dry weight and length of the fruits, fruit yield per plant, weight of a thousand seeds, number and seed weight. Regarding the seed quality, the percentage of germination, germination speed index, first count of the germination test, and electric conductivity, were evaluated. The supply of organic compost at planting had a positive effect on the production and physiological quality of the seeds of zucchini produced. The sulfur applied at topdressing improved the presence of the organic compost and also the production of seeds. Hence, it is recommended to apply $30 \mathrm{t} \mathrm{ha}^{-1}$ of organic compost at planting in association with $57 \mathrm{~kg} \mathrm{ha}^{-1}$ of $\mathrm{S}$ at topdressing for higher seed yield and quality.

Keywords: Ammonium sulfate, Cucurbita pepo, Organic matter, Seed production, Vigor.

Abbreviations: N_nitrogen; S_Sulfur; CV_coefficient of variation; DAT_ days after transplanting,

\section{Introduction}

There are several factors that can affect the production and quality of seeds, among them, the correct fertilization is one of the main determinants. Although there are several studies about plant fertilization for the commercial production of a lot of vegetables, there is still little studies relating the fertilization to the production and quality of seeds (Cardoso, 2011).

Sulfur (S) is absorbed by plants in the form of sulfate $\left(\mathrm{SO}_{4}{ }^{2-}\right)$, which is found mostly in the soil organic matter, and in a small part of the atmosphere in the form of sulfuric gas (Raij, 2011). Despite being extracted by plants in smaller quantities when compared to most of the other macronutrients, sulfur is extremely important because it is involved in the formation of proteins, in the composition of plant hormones, and is present in large quantities in amino acids, such as cysteine and methionine, which are of great relevance for plants and seeds formation (Malavolta et al., 1997). In the deficiency of this nutrient, there is inhibition of protein synthesis, resulting in lower chlorophyll content and root size (Raij, 2011).
Several studies reporting the positive effects of sulfur application on the production of several crops can be found in the literature. Broch et al. (2011), found out that the application of sulfur from different sources increased the seed yield of soybean. Raza et al. (2018), observed an increase in yield and oil content of sesame seeds, and Sahoo et al. (2018), verified that the production and quality of sunflower seeds increase accordingly to the sulfur dose applied.

In general, it is possible to find out in the literature several studies relating the use of sulfur for seed production in various vegetables, however, there is a lack of information for the zucchini crop. Regarding the crucifers, sulfur is the second most accumulated nutrient in the seeds (Magro et al. 2010; Cardoso et al. 2016), and the application of this nutrient at topdressing increases the production of broccoli seeds (Corrêa et al., 2017).

The organic matter present or added to the soil is the main sulfur source to the plants (Fernandes, 2006), therefore, the application of sulfur when the organic fertilization is realized in large quantities might be unnecessary. However, organic fertilizers are not always available in satisfactory quantities. 
Another important characteristic is that sulfur is easily leached from the rhizosphere $(0$ to $20 \mathrm{~cm})$, presenting deficiency symptoms already in the initial stage of the plant development (Hitsuda et al., 2005). Hence, the use of organic composts may help the retention of this nutrient in the rhizosphere.

According to Hobuss et al. (2007), and Stipp and Casarin (2010), even with the presence of sulfur in the atmosphere and in the soil organic matter, it is indispensable to apply $S$ from artificial sources for total supply of this nutrient to the plant, requiring careful recommendations in order to achieve success in the use of this mineral.

In Brazil, the fertilization recommendation for zucchini is usually made with no differentiation from the other cucurbit crops. Hence, there is a need for new studies in the country, regarding the doses of fertilizers used for zucchini, as well as the suitability for cultivars, seasons and cultivation regions (Silva et al., 2011). In addition, the information on fertilization for the production of zucchini seeds is even more limited. Thus, it is essential to know the practices that improve the production of zucchini seeds, as well as to verify the importance of sulfur in its production and quality.

Considering the lack of research on zucchini seeds production and the great potential of the use of sulfur and organic compost in its production, the aim of this work was to verify the influence of sulfur doses at topdressing fertilization and the supply of organic compost at planting on the production and quality of zucchini seeds.

\section{Results and discussion}

\section{Production of ripening fruits and seeds}

Regarding the characteristics of the ripe fruits, only the dry matter weight was not affected by the application of organic compost at planting, with a mean of $50 \mathrm{~g}$ per fruit (Table 3 ). The fruits presented higher values of fresh weight, diameter, and length when the organic compost was applied at planting. These three characteristics correlate since fruits with greater length and/or diameter generally present greater weight. In addition, the fruit production per plant was higher, with an increase of $607 \mathrm{~g}$ per plant, that is, $33.3 \%$ more with the presence of organic compost at planting when compared to the absence of the compost.

Rech et al., (2006), working with mineral and organic fertilization in the production of zucchini seeds did not obtain significant differences for the average fruit weight. However, they also obtained an increase of $260 \mathrm{~g}$ in fruit weight per plant using chicken manure at its maximum dose (250g plant) when compared to the control. These results show the importance of organic fertilization in the production of fruits of this species. Rossi et al., (2016) related the greater zucchini yield to the fertilization with organic compost comparing to the mineral fertilization. According to Filgueira (2013) and Monsalve et al., (2017), organic fertilization improves soil structure, increases water retention capacity and penetration, availability and absorption of nutrients, among several other benefits, resulting in increased production.

In the absence of organic compost fertilization at planting, there was no significant difference for the sulfur doses regarding the number of fruits per plant, with a general average of 1.27 fruits per plant. On the other hand, when organic compost was applied at planting it was observed that the results for the sulfur doses adjusted to the quadratic model of the regression analysis (Figure $1 \mathrm{~A}$ ). It is estimated that the maximum yield is 1.72 fruits per plant for the dose of $62 \mathrm{~kg} \mathrm{ha}^{-1}$ of $\mathrm{S}$ at topdressing when there was the application of organic compost at planting. In contrast, the highest dose of $S\left(173 \mathrm{~kg} \mathrm{ha}^{-1}\right)$ provided the lowest fruit number per plant (1.06 fruits). Therefore, when $30 \mathrm{t} \mathrm{ha}^{-1}$ of organic compost is used, the topdressing fertilization with ammonium sulfate as the source of $\mathrm{N}$, at doses higher than $62 \mathrm{~kg} \mathrm{ha}^{-1}$ of S, may be harmful to the fixation of ripe fruits of zucchini plants. Perhaps it happens due to the excess of $S$ because, besides its application at topdressing, there is a potential of $120 \mathrm{~kg} \mathrm{ha}^{-1}$ of $\mathrm{S}$ by the mineralization of the compost applied at planting.

The compost application increased the fruit yield, in number per plant, only at the rate of $57 \mathrm{~kg} \mathrm{ha}^{-1}$ of $\mathrm{S}$ at topdressing, with an increase of $60 \%$ when compared to the absence of organic compost (Figure 1A). Rech et al., (2006) found out similar values for the production of ripe fruits of zucchini for seed production: 1.33 fruits per plant. On the other hand, Lima et al., (2003) claims the production of only 1.0 fruit per plant, showing that it is common the production of a few ripening fruits per zucchini plant.

The organic compost increased the size of the fruits independently of the sulfur dose, but was less effective for the number of fruits per plant, probably because of the fact that the zucchini plant restricts itself the number of fruits when it is harvested after maturation (Cardoso and Souza Neto, 2016).

The presence of organic compost increased $33.6 \%$ and $13.6 \%$ of the weight and the number of cleaned seeds per fruit, respectively, in relation to the absence of organic compost at planting (Table 3). There was also an increase of $18.9 \%$ on the weight of one thousand seeds. In other words, the organic compost not only increased the number of seeds but also the weight of each seed. Rech et al. (2006), also obtained an increase of one thousand seeds' weight of zucchini plants produced with the application of chicken manure.

Magro et al. (2010), tested organic compost doses for the production of broccoli seeds and observed a linear increase in seed production per plant. Corrêa et al. (2017), studying doses of sulfur at topdressing and organic compost supply before planting for the production of broccoli seeds, verified that there was a linear increase of the production regarding the sulfur doses ( 0 to $230 \mathrm{~kg} \mathrm{ha}^{-1}$ of S), and the presence of the organic compost increased the number and weight of the seeds produced.

In general, organic composts present several qualities to be used as organic fertilizers, providing nutrients to the plants and promoting the increase of seed production (Magro et al., 2010; Cardoso et al., 2011). Carvalho and Nakagawa, (2012) state that the plant's nutritional needs of most species are more intense at their reproductive stage, during seed formation. Thus, the application of a slow-release natural fertilizer, such as the organic compost, positively influences the production of seeds due to nutrient supply over a longer period of time (Corrêa et al., 2017; Monsalve et al., 2017).

In the absence of organic compost, no significant difference was observed for the number of seeds per plant regarding the doses of sulfur, resulting in an average of 187 seeds per plant. In the presence of organic compost, it was estimated a maximum production of 287 seeds per plant at the rate of $67 \mathrm{~kg} \mathrm{ha}^{-1}$ of S (Figure 1B). 
Table 1. Basic chemical analysis of the soil used. FCA/UNESP, São Manuel-SP, 2016.

\begin{tabular}{|c|c|c|c|c|c|c|c|c|c|c|c|}
\hline $\mathrm{pH}$ & O.M. & $\mathrm{P}_{\text {resin }}$ & $\mathrm{Al}_{3}+$ & $\mathrm{H}+\mathrm{Al}$ & $\mathrm{K}$ & $\mathrm{Ca}$ & $\mathrm{Mg}$ & $S$ & SB & CEC & V\% \\
\hline $\mathrm{CaCl}_{2}$ & $\mathrm{~g} \mathrm{dm}^{-3}$ & $\mathrm{mg} \mathrm{dm}^{-3}$ & & - $\mathrm{mm}$ & $d m$ & & & & & & \\
\hline 5,3 & 14 & 159 & 20 & & 2 & 32 & 8 & 5 & 42 & 62 & 67 \\
\hline
\end{tabular}

Source: Natural Resources Department's Fertilizers and Correctives Laboratory - Soil Science Area - FCA/UNESP.

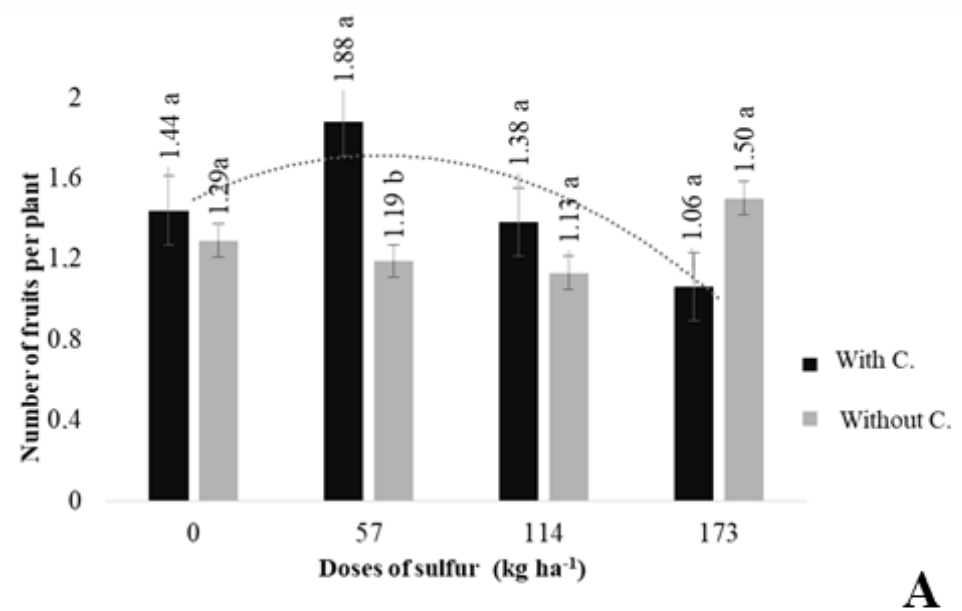

$$
\begin{aligned}
& \begin{array}{cc}
\mathrm{y}_{\mathrm{p}}=-0.000055 \mathrm{x}^{2}+0.0068 \mathrm{x}+1.4959 & \mathrm{y}_{\mathrm{a}}=1.28 \\
\mathrm{R}^{2}=0.80^{*} &
\end{array} \\
& \begin{array}{l}
\pi \\
\text { aे } \\
\text { क } \\
\text { ल }
\end{array}
\end{aligned}
$$

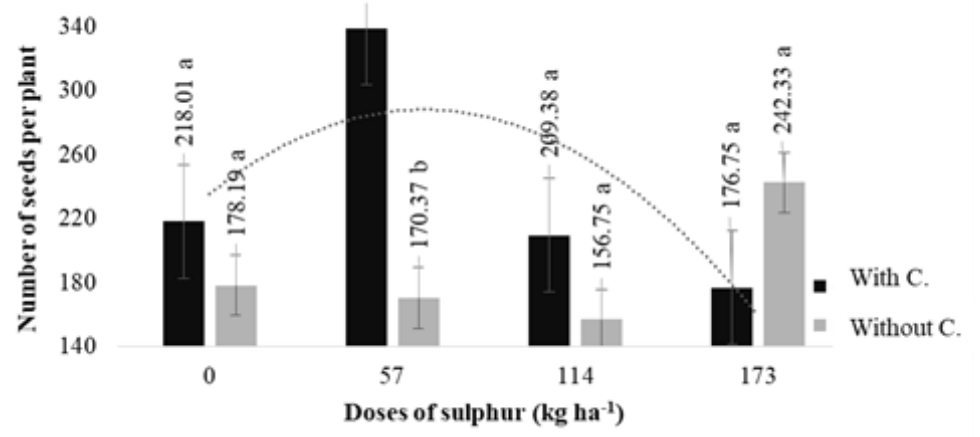

$$
\begin{array}{ccc}
\mathrm{y}_{\mathrm{p}}=-0.0113 \mathrm{x}^{2}+1.5182 \mathrm{x}+235.89 & \mathrm{y}_{\mathrm{a}}=186.91 & \text { B } \\
\mathrm{R}^{2}=0.59^{*} &
\end{array}
$$

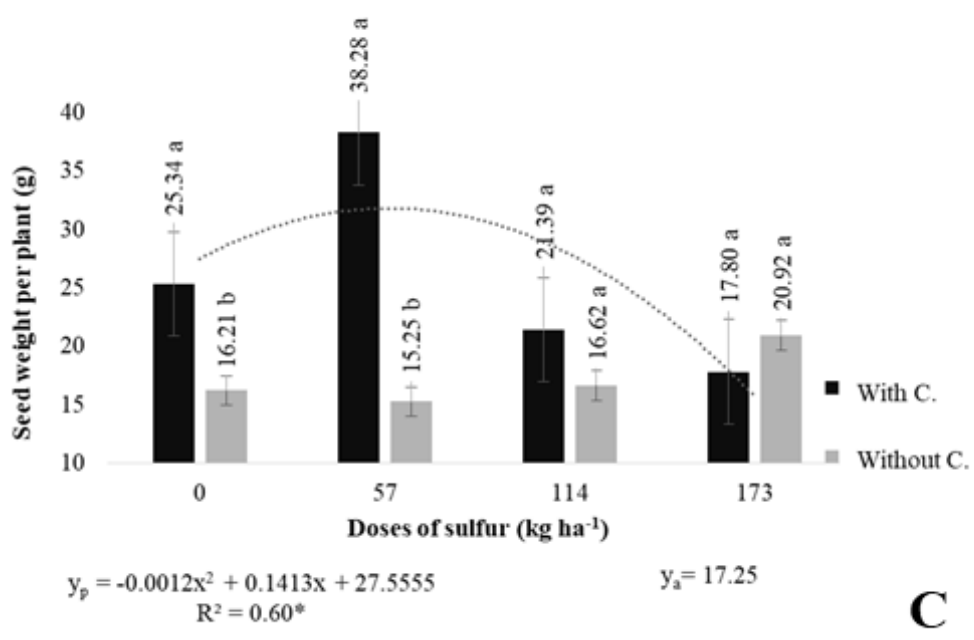

Fig 1. Number of fruits (A), number of seeds (B) and seed weight (C) per plant as a function of the sulfur doses at topdressing with the presence (yp) and absence of organic compost (ya) at planting, and averages with and without organic compost for each dose of sulfur. Means with and without organic compost followed by the same letter, for each dose of sulfur, do not differ from each other by the Tukey test at $5 \%$ probability $(p<0.05)$. 
Table 2. Chemical analysis of the organic compost supplied at planting for the production of zucchini seeds. FCA/UNESP, São Manuel-SP, 2016

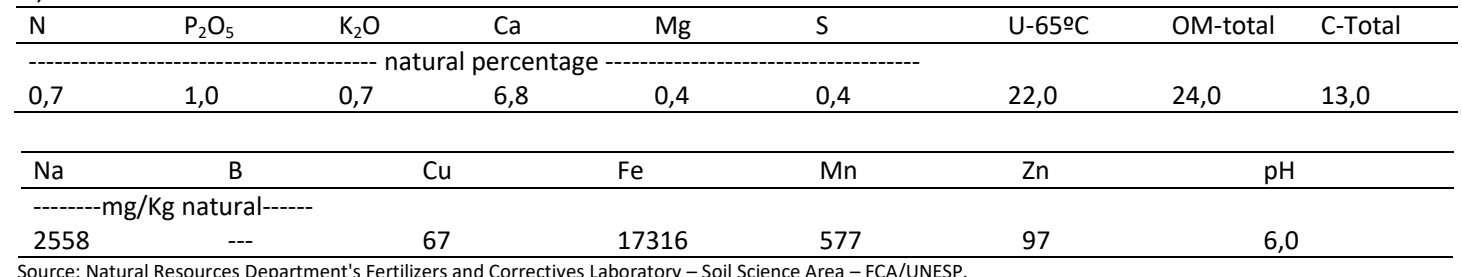

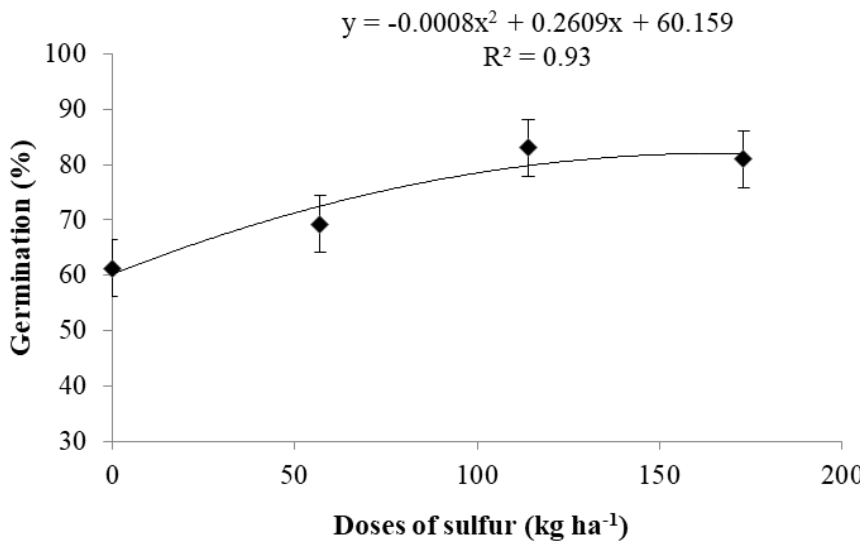

Fig 2. Percentage of germination of zucchini seeds as a function of sulfur doses at topdressing fertilization.

Table 3. Average fruit weight (FW), diameter (FD) and length (FL), fruit dry weight (FDW), fruit yield per plant (FYP), thousand seed weight (TSW), number (NSF) and seed weight (SWF) per fruit in the presence and absence of fertilization with organic compost at planting.

\begin{tabular}{|c|c|c|c|c|}
\hline Organic compost & $\begin{array}{l}\text { FW } \\
\left(\text { (kg fruit }^{-1}\right)\end{array}$ & $\begin{array}{l}\text { FD } \\
(\mathrm{cm})\end{array}$ & $\begin{array}{l}\mathrm{FL} \\
(\mathrm{cm})\end{array}$ & $\begin{array}{l}\text { FDW } \\
\text { (g fruit }^{-1} \text { ) }\end{array}$ \\
\hline Presence & $1.690 \mathrm{a}$ & $9.1 \mathrm{a}$ & $37.1 \mathrm{a}$ & $49.04 \mathrm{a}$ \\
\hline \multirow[t]{2}{*}{ Absence } & $1.440 \mathrm{~b}$ & $8.7 b$ & $34.9 \mathrm{~b}$ & $51.05 \mathrm{a}$ \\
\hline & $\begin{array}{l}\text { FYP } \\
\left(\text { kg plant }^{-1}\right)\end{array}$ & $\begin{array}{l}\text { TSW } \\
\text { (g) }\end{array}$ & NSF & $\begin{array}{l}\text { SWF } \\
\text { (g fruit }^{-1} \text { ) }\end{array}$ \\
\hline Presence & $2.430 \mathrm{a}$ & $109.5 \mathrm{a}$ & $164.5 \mathrm{a}$ & $17.99 \mathrm{a}$ \\
\hline Absence & $1.823 b$ & $92.1 \mathrm{~b}$ & $144.9 \mathrm{~b}$ & $13.47 \mathrm{~b}$ \\
\hline
\end{tabular}

Means followed by the same letter in the columns do not differ from each other by the Tukey test at $5 \%$ probability $(p<0.05)$.

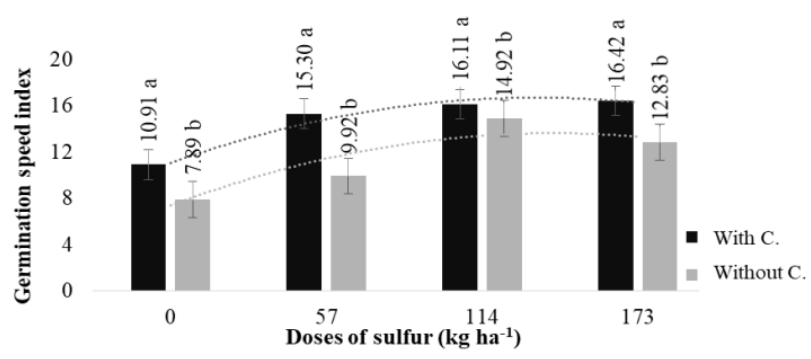

$\mathrm{y}_{\mathrm{p}}=-0.00031 \mathrm{x}^{2}+0.08348 \mathrm{x}+11.07196 \quad \mathrm{y}_{\mathrm{a}}=-0.000318 \mathrm{x}^{2}+0.08924 \quad$ A

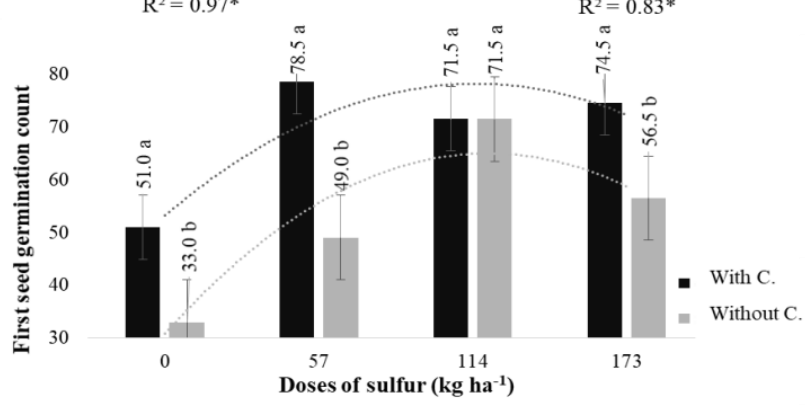

$\begin{array}{ccc}y_{p}=-0.0018 x^{2}+0.4278 x+53.2802 & y_{a}=-0.0024 x^{2}+0.5699 x+30.791 \\ R^{2}=0.78^{*} & \text { B }\end{array}$

Fig 3. Germination speed index (A) and first seed germination count (B) of zucchini seeds as a function of sulfur doses at topdressing with the presence (yp) and absence (ya) of organic compost at planting, and means with and without organic compost for each dose of sulfur. Means of the treatments with and without organic compost followed by the same letter do not differ from each other, within each sulfur dose, by the Tukey test at $5 \%$ probability $(p<0.05)$. 
Table 4. Averages for the characteristics of the percentage of germination, and average germination time, in the presence and absence of fertilization with organic compost at planting.

\begin{tabular}{lll}
\hline Organic compost & $\begin{array}{l}\text { Germination } \\
(\%)\end{array}$ & $\begin{array}{l}\text { Average germination time } \\
\text { (Days) }\end{array}$ \\
\hline Presence & $81.13 \mathrm{a}$ & $3.2 \mathrm{~b}$ \\
Absence & $66.13 \mathrm{~b}$ & $3.5 \mathrm{a}$ \\
\hline
\end{tabular}

Means followed by the same letter in the columns do not differ from each other by the Tukey test at $5 \%$ probability $(p<0.05)$.

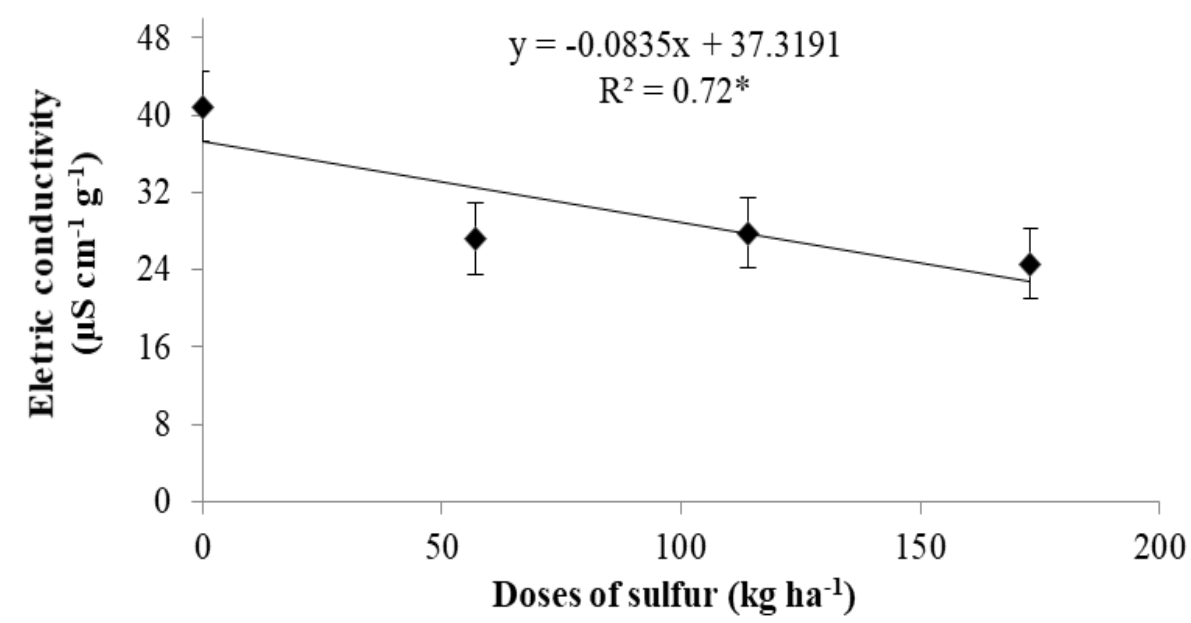

Fig 4. Electric conductivity of zucchini seeds as a function of sulfur doses at topdressing fertilization.

A similar result was observed for the seed weight per plant, where there was no effect for the $\mathrm{S}$ doses when no organic compost was applied, with an average of $17.25 \mathrm{~g}$ of seeds per plant. In contrast, there was a quadratic adjustment when the zucchini plants were fertilized with organic compost at planting, presenting a maximum yield of $32 \mathrm{~g}$ of seeds per plant at the dose $59 \mathrm{~kg} \mathrm{ha}^{-1}$ of S (Figure 1C). These results are probably a consequence of the greater number of fruits per plant, once this characteristic also presented a quadratic adjustment in the presence of organic compost, with a maximum number of fruits at a slightly similar dose, $62 \mathrm{~kg} \mathrm{ha}^{-1}$ of S (Figure 1A).

Regarding the number of seeds per plant, the application of organic compost at planting provided a higher number of seeds only at the dose $57 \mathrm{~kg} \mathrm{ha}^{-1}$ of $\mathrm{S}$, resulting in a production of 339 seeds per plant, almost $100 \%$ more when compared to the absence of organic compost (170 seeds per plant) (Figure 1B).

In relation to the seeds ' weight per plant, the fertilization with organic compost at planting was superior to the treatments without compost just at the lower $S$ doses $(0$ and $\left.57 \mathrm{~kg} \mathrm{ha}^{-1}\right)$. The results showed an increase higher than $100 \%$ in the seeds ' weight per plant at the rate of $57 \mathrm{~kg} \mathrm{ha}^{-1}$ of $\mathrm{S}$ (Figure 1C). At the highest S doses (114 and $173 \mathrm{~kg} \mathrm{ha}^{-1}$ of S) there was no difference for the presence or absence of organic compost at planting.

It can be observed that the application of organic compost at planting associated with $57 \mathrm{~kg} \mathrm{ha}^{-1}$ of $\mathrm{S}$ at topdressing results in productivity gains, with a significant increase in fruit production (Figure 1A), number of seeds (Figure 1B), and seed weight per plant (Figure $1 C$ ), and also that higher $S$ rates can be harmful for the production of zucchini seeds.

Yamada et al., (2007) reported that the absorption of sulfur is directly linked to $\mathrm{N}$ absorption, and when there is an excess of $\mathrm{S}$ a reduction in production may occur, probably due to toxicity, however, there are no studies about this probable effect. Thus, doses higher than $62 \mathrm{~kg} \mathrm{ha}^{-1}$ of $\mathrm{S}$ associated with $30 \mathrm{t} \mathrm{ha}^{-1}$ of organic compost, which already has a potential of $120 \mathrm{~kg} \mathrm{ha}^{-1}$ of $\mathrm{S}$, may be deleterious to the production of zucchini seeds.

According to Araújo et al. (2015), sulfur is the macronutrient less extracted by the zucchini plants. Trani and Van Raij (1997), and Filgueira (2013), do not recommend the application of sulfur for the production of immature fruits, while Vitti and Heirinchs (2007) recommend that for an adequate $S$ supply it is necessary to apply about 40 to $50 \mathrm{~kg}$ $\mathrm{ha}^{-1}$ of $\mathrm{S}$ for the production of most of the vegetable crops. This recommended dose is slightly lower than that estimated for the maximum seed yield in the presence of organic compost.

\section{Seed quality}

The presence of organic compost increased the percentage of germination ( $15 \%$ higher) and reduced the average germination time (Table 4). These results show the importance of the application of organic compost at planting for the quality of zucchini seeds. Alves et al. (2005), also observed increased germination percentage of coriander seeds when using cattle manure. However, Magro et al. (2010), and Cardoso et al. (2011), studying doses of organic compost for the production of broccoli and lettuce seeds, respectively, observed that the compost affected the production of seeds, but did not change their quality. Corrêa et al. (2017), in research with broccoli, obtained similar results. These results show the importance of research for each species, which respond differently to fertilization techniques.

Regarding the sulfur doses, a quadratic adjustment of the regression analysis was observed, with maximum germination estimated at $81.5 \%$ at the rate of $163 \mathrm{~kg} \mathrm{ha}^{-1}$ of $\mathrm{S}$, remaining practically stable at the higher $\mathrm{S}$ doses (Figure 2). An interaction between the studied factors was observed for the germination speed index (GSI). The values of GSI 
were adjusted to the quadratic model and increased until $135 \mathrm{~kg} \mathrm{ha}^{-1}$ of $\mathrm{S}$ in the presence of organic compost and until $140 \mathrm{~kg} \mathrm{ha}^{-1}$ of $\mathrm{S}$ in its absence, when the values were practically stabilized (Figure 3A). A similar result was observed for the first germination count, with a more pronounced increase at the first $S$ doses, and stabilization at the two higher $\mathrm{S}$ doses, both in the absence and presence of organic compost (Figure 3B).

The electrical conductivity (Figure 4) presented a linear adjustment regarding the sulfur doses. During the process of seed's imbibition, the leaching decreased according to the $S$ doses increase, presenting a higher speed of establishment of the integrity of the membrane. In other words, seed vigor increases along with the increase of the $S$ dose, a fact that is independent of the supply of organic compost at planting. According to Marcos Filho (2015), the loss of high quantities of exudates during the imbibition process in the field may attract microorganisms that impair seedling emergence since sugars, amino acids, proteins, enzymes, and organic ions, such as $\mathrm{K}^{+}, \mathrm{Ca}^{+2}, \mathrm{Mn}^{+2}, \mathrm{Mg}^{+2}$, and $\mathrm{Na}^{+}$, are lost by the seeds to the soil or substrate.

In general, the importance of the organic compost associated with sulfur in the quality of zucchini seeds is visible. However, when significant, sulfur affected the production only in the presence of organic compost at planting (Figures $1 \mathrm{~A}$ and $1 \mathrm{C}$ ), with a quadratic adjustment, that is, $\mathrm{S}$ in excess impaired production. However, regarding the seeds' quality (Figures 2 and 4), sulfur was beneficial both in the presence and absence of organic compost and, in general, higher $\mathrm{S}$ doses did not affect the quality so much. The sulfur is likely to indirectly affect the germination percentage and vigor of zucchini seeds because it is directly related to the metabolism of $\mathrm{N}$. Plants that receive $\mathrm{N}$ and $\mathrm{S}$ in adequate quantities will present good N/S ratio, and both nutrients may influence the quality of the proteins produced (Yamada et al., 2007). Proteins, after water, are the most important substances in the seed for the formation of new tissues (Marcos Filho, 2015). Among the studies involving fertilization and seed production, nitrogen is the mineral that most interferes in the production and quality of most of the crops, chiefly due to its relation with the protein content of the seeds (Marcos Filho, 2015). Oliveira et al. (2003), tested different doses and sources of nitrogen for the production of bean pod seeds and concluded that ammonium sulfate is the best source of $\mathrm{N}$ for seed production on the field, affecting both the production and quality. On the other hand, Corrêa et al. (2017), stated that sulfur did not influence the quality of broccoli seeds, only its production.

\section{Material and methods}

\section{Area characterization}

The experiment was conducted at the Experimental Farm São Manuel, located in the municipality of São Manuel-SP, belonging to the College of Agricultural Sciences (FCA) of the São Paulo State University (UNESP), campus of Botucatu-SP. The geographical coordinates of the area are $22^{\circ} 46^{\prime} \mathrm{S}$, $48^{\circ} 34^{\prime} \mathrm{W}$, and $740 \mathrm{~m}$ asl.

According to the Köppen criteria, the climate is classified as a cfa (warm temperate), humid, with an annual average rainfall of 1,376 $\mathrm{mm}$ (Cunha and Martins, 2009), with a maximum annual average temperature of $27.1{ }^{\circ} \mathrm{C}$ and minimum of $14.5^{\circ} \mathrm{C}$ (Cepagri 2015). The soil of the area is classified as a Typical Red Dystrophic Latosol (Ferralsols, Oxisols). The results from the soil chemical analysis are presented in Table 1. It is a sandy soil with $84 \%$ sand, $5 \%$ silt, and $11 \%$ clay

A total of eight treatments were studied in a randomized block design with a factorial scheme $4 \times 2$, with four sulfur doses at topdressing [0 (control - without S), 57, 114, and $173 \mathrm{~kg} \mathrm{ha}^{-1}$ of S], in the presence $\left(30 \mathrm{tha}^{-1}\right)$ and absence of organic compost supply at planting. Each treatment was composed of four replicates, containing 16 plants per plot from which four were considered useful. The organic compost dose applied at planting $\left(30 \mathrm{t} \mathrm{ha}^{-1}\right)$ was obtained through the average dose recommended by Trani and Raij (1997) for zucchini production.

The chemical analysis from the organic compost is presented in Table 2.

\section{Treatments and experimental design}

The sulfur doses applied were calculated considering the use of ammonium sulfate as the source of $\mathrm{N}$ at topdressing. Considering the maximum dose of $\mathrm{N}$ in topdressing $(150 \mathrm{~kg}$ $\mathrm{ha}^{-1}$ of N) recommended by Trani and Raij (1997), and 100\% of $\mathrm{N}$ as ammonium sulfate $(20 \% \mathrm{~N}$ and $23 \% \mathrm{~S})$, we have the maximum dose of $S\left(173 \mathrm{~kg} \mathrm{ha}^{-1}\right)$. The fertilizer urea $(45 \% \mathrm{~N})$ was used to achieve $150 \mathrm{~kg} \mathrm{ha}^{-1}$ of $\mathrm{N}$ in the treatments with lower $\mathrm{S}$ doses in order to standardize the $\mathrm{N}$ fertilization in all treatments.

\section{Experimental conduction}

The nitrogen, phosphorus and potassium fertilization at planting was conducted using the formulation 4-14-8 according to the recommendation of Trani and Raij (1997) and was applied along with the organic compost in the treatments which received the compost at planting, and in the treatments without the compost, only the N-P-K formulation was applied. The topdressing fertilization was divided into three applications during the zucchini production cycle, with an average interval of 15 days with the first application occurring 15 days after seedlings transplanting (DAT). In addition to $\mathrm{S}$ and $\mathrm{N}$, potassium was also supplied at topdressing fertilization at the rate of $120 \mathrm{~kg}$ $\mathrm{ha}^{-1}$ of $\mathrm{K}_{2} \mathrm{O}$ as potassium chloride $(\mathrm{KCl})$.

The zucchini cultivar Caserta was used in the experiment, and the seedlings were transplanted to beds 15 days after sowing, in alternate rows spaced $0.50 \mathrm{~m}$ between rows and $0.80 \mathrm{~m}$ between plants. The irrigation was performed daily, except on rainy days, at the rate of $3 \mathrm{~mm}$ per day through a sprinkler irrigation system.

All zucchini fruits were harvested 62 DAT when they were completely mature. After harvest, the fruits were stored and remained at rest for 15 days in order to reach uniformity of the seed's physiological maturation (Cardoso and Souza Neto, 2016).

The seeds were extracted manually. After drying, the seeds were stored in a dry chamber $\left(40 \% \mathrm{RH}\right.$ and $\left.20^{\circ} \mathrm{C}\right)$ in order to stabilize the water content at $8 \%$. After this period, the seeds were cleaned through a density seed separator ('De Leo Type 1' model), obtaining the cleaned seeds that were used for the evaluations, excluding the immature and poorly formed ones. 


\section{Production characteristics evaluated}

The characteristics evaluated for yield were the number of ripe fruits per plant, fresh and dry fruit weight, fruit diameter and length, production of seeds per fruit and per plant, and weight of 1000 seeds.

\section{The following analyses were performed in order to evaluate seed quality}

I) Germination test: according to the Rules of Seed Analysis (Brazil, 2009), the seeds were placed on two sheets of germinating paper, moistened with water 2.5 times the dry weight of the papers, covered with another sheet of germinating paper, rolled up, and then placed in an upright position in a seed germination chamber at a temperature of $25^{\circ} \mathrm{C}$. Four replicates of 50 seeds were used for the test of germination. The number of normal seedlings germinated was counted at the $4^{\text {th }}$ and $8^{\text {th }}$ days after sowing;

II) The first count of the germination test: corresponds to the percentage of seeds germinated at the fourth day after sowing during the germination test (Brazil, 2009);

III) Germination speed index (GSI): this test was carried out within the germination test and calculated taking into consideration the values of seeds germinated day by day, by summing the number of seedlings germinated each day (non-cumulative) and dividing by the total number of days (Maguire, 1962). The evaluations were conducted every day until the $8^{\text {th }}$ day after sowing.

IV) Electrical conductivity test: this test was conducted using the mass test method, with four subsamples of 50 seeds, where each subsample was previously weighed and then placed in a plastic cup containing $75 \mathrm{~mL}$ of deionized water for a period of 8 hours, at $30^{\circ} \mathrm{C}$, in a BOD chamber (Vieira and Dutra, 2006). A conductivity meter was used, and the results were expressed in $\mu \mathrm{S} \mathrm{cm}^{-1} \mathrm{~g}^{-1}$.

\section{Statistical analysis}

The results were submitted to analysis of variance and the regression analysis was performed to verify the effect of the sulfur doses on the evaluated characteristics. Tukey test at $5 \%(p<0.05)$ of probability was used for comparing the presence and absence of organic compost at planting. Data processing was performed by the software of statistical analysis SISVAR 5.3 (Ferreira, 2011).

\section{Conclusion}

The presence of organic compost at planting had a positive effect on the production and physiological quality of zucchini seeds. The sulfur fertilization at topdressing improves seeds' physiological quality and, in the presence of organic compost at planting, its production. Hence, the application of organic compost at planting associated with $57 \mathrm{~kg} \mathrm{ha}^{-1}$ of sulfur at topdressing is recommended in order to obtain higher seed quality and yield.

\section{Acknowledgments}

To the National Council for Scientific and Technological Development (CNPq) and to the Coordination for the Improvement of Higher Education Personnel (CAPES) for the scholarships granted to the authors.
Alves EU, Oliveira AP, Bruno RLA, Sader R, Alves AU (2005) Yield and physiological quality of coriander seeds cultivated with organic and mineral fertilization. Braz J Seeds. 27: 132-137.

Araújo HS, Cardoso All, Oliveira Júnior MX, Magro FO (2015) Macronutrient contents and extraction in zucchini as a function of doses of potassium in coverage. Braz J Agric Sci.10: 389-395.

Brazil. Ministry of agriculture and agrarian reform (2009) Rules for seed analysis. MAPA, Brasília.

Broch DL, Pavinato PS, Possentti JC, Martin TN, Quiqui EMD (2011) Produtividade da soja no cerrado influenciado pelas fontes de enxofre. R Cienc Agronômica. 42(3): 791-796.

Cardoso AAI, Claudio MTR, Magro FO, Freitas PGN (2016) Phosphate fertilization on production and quality of cauliflower seeds. C Rural. 46: 1337-1343.

Cardoso AAI, Ferreira KP, Vieira Júnior RM, Alcarde C (2011) Changes in soil properties fertilized with organic compost and effect on lettuce seed quality. Braz Horticulture. 29: 594-599.

Cardoso All (2011) Nutrition and fertilization in vegetable seed production. In: Nascimento WM (ed) Vegetable: technology in vegetable seed production. Embrapa Hortaliças, Brasília.

Cardoso All, Souza Neto IL (2016) Improvement of pumpkin, zucchini and blackberry. In: Nick C, Borém A (ed) Improvement of Vegetables, 1rd edn. UFV, Brazil.

Carvalho NM, Nakagawa J (2012) Seeds: science, tecnology and production. 5rd edn. FUNEP, Jaboticabal.

Cepagri - Center for meteorological and climatic research applied to agriculture (2015) Clima dos municípios paulistas. [ cited 2017 july 10]; Available from: https://www.cpa.unicamp.br/outras-

informacoes/clima_muni_563.html.

Corrêa CV, Gouveia AMS, Tavares AEB, Evangelista RM, Cardoso All, Mendonça VZ, Martins BNM, Lanna NBL (2017) Sulphur (S) topdressing and organic compost in the production, quality and nutrients accumulation in broccoli seeds at planting. Aust J Crop Sci. 11: 542-547.

Cunha AR, Martins D (2009) Classificação climática para os municípios de botucatu e são manuel, sp. Irriga. 14: 1-11.

Fernandes MS (2006) Mineral nutrition of plants. Sociedade Brasileira de Ciências do Solo, Viçosa.

Ferreira DF (2011) Sisvar: a computer statistical analysis system. Sci Agrotechnology. 35(6): 1042-1046.

Filgueira FAR (2013) New manual of olericultura: modern agro-technology in the productionand commercialization of vegetables. 3nd edn. UFV, Viçosa.

Hitsuda K, Yamada M, Dirce K (2005) Solo e gestão de culturas e exigência de enxofre de oito culturas em estágios iniciais de crescimento. Agron J. 97: 155-159.

Hobuss C, Venzke D, Gouveia D, Gobel L, Krolow M, Devantier P, Alves R, Jacondino V (2007) Ciclo do enxofre. Universidade Federal de Pelotas, Pelotas.

Lima MS, Cardoso All, Verdial MF (2003) Plant spacing and pollen quantity on yield and quality of squash seeds. Braz Horticulture. 21: 443-447.

Magro FO, Arruda N, Casa J, Salata AC, Cardoso All, Fernandes DM (2010) Organic compound in the production and quality of broccoli seeds. Sci agro-tech. 34: 596-602. 
Maguire JD (1962) Speed of germination-aid selection and evaluation for seedling emergence and vigor. Crop Sci. 2: 176-177.

Malavolta E, Vitti GC, Oliveira SA (1997) Evaluation of the nutritional status of plants: principles and applications. 2nd edn. Potafós, Piracicaba.

Marcos Filho J (2015) Seed physiology of cultivated plants. 2nd edn. Abrates, Londrina.

Monsalve OI, Gutiérrez JS, Cardona WA (2017) Factores que intervienen em el processo de mineralización de nitrógeno cuando son aplicadas enmeiendas orgânicas al suelo. $\mathrm{R}$ Colomb C Hortic. 11: 200-209.

Oliveira AP, Pereira EL, Bruno RLA, Alves EU, Costa RF, Leal RFR (2003) Production and physiological quality of beanpod seeds as a function of nitrogen sources and doses. Braz J Seeds. 25: 49-55.

Raij BV (2011) Fertilidade do solo e manejo de nutrientes. International Plant Nutrition Institute, Piracicaba.

Raza MA, Feng LY, Manaf A, Wasaya A, Ansar M, Hussain A, Khalid MHB, Iqbal N, Xi ZJ, Chen YK, Chen JX, Yang F, Yang W (2018) Sulphur application increases seed yield and oil contente in sesame seeds under rainfed conditions. F Crop Res. 218: 51-58.

Rech EG, Franke LB, Barros IBI (2006) Organic and mineral fertilization in the production of zucchini seeds. Braz J Seeds. 28: 110-116.

Rossi G, Socciarelli S, Aromolo R, Ciampa A, Beni C (2016) The effects of mineral and organic fertilizers on zucchini
(Cucurbita pepo L) investigated by the multiparameters analyses and magnetic resonance imaging. Agrochimica. 60: 275-287.

Sahoo P, Brar AS, Sharma S (2018) Effect of methods of irrigation and Sulphur nutrition on seed yeld, economic and bio-physical water productivity of two sunflower (Helianthus annuus L.) hybrids. Agric W Management. 206: 158-164.

Silva LV, Oliveira GQ, Silva MG, Nagel PL, Machado MMV (2011) Nitrogen doses in coverage in two cultivars of zucchini in the city of aquidauana-ms. Braz J Agric Sci. 6 : 447-451.

Stipp SR, Casarin VA (2010) A importância do enxofre na agricultura brasileira. IPNI, Piracicaba.

Trani PE, Van Raij B (1997) Vegetables. In: Van Raij B (ed) Recommendations of fertilization and liming for the State of São Paulo, 2rd edn. Instituto Agronômico \& Fundação IAC, Campinas.

Vieira RD, Dutra AS (2006) Teste de condutividade elétrica para a avaliação do vigor de sementes de abobrinha. Braz $J$ Seeds. 28: 117-122.

Vitti G, Heirinchs R (2007) Traditional and alternative forms of obtaining and using nitrogen and sulfur: a holistic view. In: Yamada T, Abdalla RS, Vitti GC (ed) Nitrogen and sulfur in brazilian agriculture, 1 rd edn. UFV, Piracicaba.

Yamada T, Abdalla SRS, Vitti GC (2007) nitrogen and sulfur in brazilian agriculture. 1nd edn. UFV, Piracicaba. 